\title{
PENGEMBANGAN MODEL KONSELING LOGO UNTUK MENCEGAH PEYALAHGUNAAN NARKOBA, PSIKOTROPIKA DAN ZAT ADIKTIF LAINNYA PADA PARA SISWA DI BALI
}

\author{
Kadek Suranata \\ e-mail: sura@konselor.org \\ Jurusan Bimbingan Konseling, Universitas Pendidikan Ganesha \\ Singaraja, Indonesia
}

\begin{abstract}
Abstrak
Penelitian ini bertujuan untuk mengembangkan model konseling logo untuk mencegah penyalahgunaan narkoba, psikotropika, dan zat adiktif lainnya (Napza) pada para siswa di Provinsi Bali. Secara lebih rinci, untuk: (1) mendeskripsikan kecenderungan penyalahgunaan napza para siswa di Bali, (2) mendeskripsikan persepsi siswa terhadap upaya pencegahan penyalahgunaan napza yang dilakukan di sekolah, (3) mengetahui validitas teoretik rancangan model konseling logo, (4) mengetahui pengaruh model konseling logo terhadap kecenderungan penyalahgunaan napza siswa. Penelitian pengembangan ini dilakukan melalui tujuh langkah pokok, yaitu: (1) research and information collecting, (2) planning, (3) developing preliminary form of product, (4) preliminary field testing and product revision, (5) main field test and product revision, (6) operational field test and product revision dan (7) dessemination implementation and institutionalization. Populasi penelitian terdiri dari pakar dan praktisi bimbingan konseling di sekolah serta para siswa pada SMP,SMA,SMK di Provinsi Bali. Sampel penelitian ditentukan dengan teknik multistage random sampel. Hasil penelitian menunjukkan bahwa: (1) sebanyak $64,15 \%$ dari 332 responden memiliki kecenderungan penyalahgunaan napza pada kategori sedang, $25,10 \%$ pada kategori tinggi, dan $10,25 \%$ pada kategori rendah, (2) sebanyak $81 \%$ siswa mempersepsikan telah dilakukan upaya pencegahan penyelahgunaan napza di sekolah dan $61 \%$ diantaranya mempersepsikan upaya pencegahan dilakukan oleh konselor sekolah, (3) uji validitas teoretik menunjukkan model konseling logo memiliki indek validitas yang baik ( $R$ sebesar 0,90); (4) terdapat perbedaan penurunan signifikan kecenderungan penyalahgunaan napza siswa yang mengikuti konseling logo dengan yang mengikuti konseling secara konvensional (t sebesar $-19,654 p<0,05$, dan pada amatan lanjut $t$ sebesar $-14,443 p<0,05$ ). Penelitian akan dilanjutkan pada tahap II dengan fokus pada uji coba efektifitas model pada populasi yang lebih luas.
\end{abstract}

Kata-kata kunci: penyalahgunaan napza, konseling logo.

\begin{abstract}
This study aims to develop a counseling logo model to prevent drug abuse, psychotropic drugs, and other addictive substances on the students in the province of Bali. In more detail: (1) to describe the tendency of the student drug abuse in Bali, (2) describe student perceptions of drug abuse prevention efforts conducted in schools, (3) determine the validity of theoretical models of counseling logo design, (4) determine the effect counseling logo against drug abuse trend in
\end{abstract}


students. This development research is done through seven main steps, namely: (1) research and collecting information, (2) planning, (3) developing a preliminary form of the product, (4) preliminary field testing and product revision, (5) playing field test and product revision, (6) field operational test and product revision and (7) dessemination implementation and institutionalization. Population consisted of experts and practitioners in school counseling as well as the students at the junior high, high school, vocational school in the province of Bali. Sample was determined by multistage random sampling technique. The results showed that: (1) as much as $64.15 \%$ of the 332 respondents have a tendency to drug abuse in the moderate category, $25.10 \%$ in the high category, and $10.25 \%$ in the low category, (2) as much as $81 \%$ of students perceive has drug abuse prevention efforts in schools and $61 \%$ of them perceive prevention efforts made by the school counselor, (3) the validity of theoretical models of counseling logo show has good validity index ( $R$ 0.90), (4) there is a significant difference in the decline trend drug abuse counseling students who take the logo with the following conventional counseling (on the post tets $t$ is $-19.654, p<0.05$, and on follow up test $t$ is $-14.443, p<0,05$ ). This research will continue in phase II studies with a focus on determine the effectiveness of the model in the wider population.

Key words: drug abuse, counseling logo.

\section{PENDAHULUAN}

Penyalahgunaan napza di kalangan siswa dan pelajar adalah masalah yang menghawatirkan dan mengancam kelangsungan hidup bangsa. Badan narkotika Nasional atau BNN (2005: 37) menyebutkan bahwa Napza adalah singkatan dari narkotika, psikotropika dan bahan adiktif lainnya, meliputi zat alami atau sintetis yang bila dikonsumsi menimbulkan perubahan fungsi fisik, serta menimbulkan ketergantungan. Ancaman yang ditimbulkan adalah rusaknya generasi muda yang diharapkan sebagai sendi-sendi penerus bangsa.

Penyalahgunaan napza di kalangan siswa dapat menimbulkan efek negatif berupa bahaya baik bagi penyalahguna itu sendiri berupa rusaknya mental dan bahkan kematian, bahaya bagi keluarga, bagi lembaga sekolah. Lebih jauh persoalan penyalahgunaan napza dapat memberikan kerugian bagi masyarakat, bangsa dan negara berupa tidak produktifnya masyarakat dan meningkatnya tingkat kejahatan. Indonesia merupakan negara yang wilayahnya termasuk jalur penyelundupan, peredaran gelap napza. Bahkan masyarakat Indonesia juga sudah banyak ditemukan menjadi penyalahgunaan, bahkan sebagai produksi atau penghasil napza. Sehingga demikian Indonesia sebenarnya sangat rentan dengan masalah penyalahgunaan napza. Setiap hari, hampir terdapat 20 orang di Indonesia yang meregang nyawa akibat narkoba, serta ratusan siswa dan pelajar setiap tahunnya kehilangan masa depannya karena terbelenggu sebagai pecandu narkoba.

Studi identifikasi kecenderungan penyalahgunaan napza oleh para siswa pelajar di Bali menunjukkan ciri-ciri mereka memiliki kecenderungan sebagai penyalahguna narkoba, psikotropika, dan obat terlarang. Seperti, kebiasaan merokok, konsumsi alkohol, bahkan diantaranya diketahui sebagai pecandu narkoba, dan sejenisnya (Suranata, 2009). Temuan tersebut merupakan gambaran kecil lemahnya generasi muda kita dalam menyiapkan diri terhindar dalam penyalahgunaan napza. Apalagi semakin kuatnya dorongan faktor-faktor negatif Jurnal Pendidikan Indonesia | 186 
lingkungan di sekitar siswa yang mengancam terbelenggunya mereka dalam penyalahgunaan napza.

Permasalahan tersebut dikaitkan dengan tugas dan peranan konselor sekolah sebagai salah satu komponen dalam sistem pendidikan di persekolahan dalam mengemban tugas untuk mengembangkan potensi siswa. Termasuk juga menghindarkan siswa ke dalam hal-hal negatif yang menjerumuskan dan menghambat perkembangannya, merupakan suatu tantangan untuk memacu kompetensi profesionalitas sebagai pendidik dengan mengembangkan dan menerapkan pendekatan, model, strategi serta teknikteknik konseling yang lebih inovatif.

Terdapat beberapa penyebab siswa terlibat dalam kasus penyalahgunaan Napza, hal-hal tersebut dapat dididentifikasi sebagai berikut: (1) dipengaruhi kawan, siswa masih memiliki jiwa yang labil dan masih mencari jati diri, sehingga mudah dipengaruhi dan ikut-ikutan kawan; (2) rasa ingin tahu yang tinggi, siswa suka mencoba hal-hal yang baru, termasuk yang dapat membahayakan dirinya; (3) solidaritas kelompok, kuatnya rasa solidaritas siswa menyebabkan ia sulit menolak tekanan anggota kelompoknya termasuk tawaran narkoba; (4) ingin tampil menonjol, siswa sering mencari perhatian dengan harapan terlihat berani, percaya diri dan tampil beda, (5) menghilangkan rasa bosan dan stress, siswa sering menganggap narkoba dapat menyelesaikan masalah- masalah yang dihadapinya, (6) rendahnya mental dan spiritual, siswa yang sedikit memahami makna hidupnya cenderung mencari pelarian untuk mengatasi masalahnya, seperti terlibat dalam penyalahgunaan napza, (7) keinginan memberontak, sebagian siswa menggunakan narkoba sebagai reaksi pemberontakan terhadap kekuasaan orang tua (Suranata, 2009)

Iklim lingkungan kehidupan yang kurang sehat, seperti: maraknya tayangan pornografi, penyalahgunaan alat kontrasepsi, minuman keras, dan obatobatan terlarang/ napza yang tidak terkontrol, ketidak harmonisan dalam kehidupan keluarga;dan dekadensi moral orang dewasa sangat mempengaruhi pola perilaku gaya hidup anak (terutama pada usia remaja) yang cenderung menyimpang dari kaidah-kaidah moral (akhlak yang mulia), seperti: pelanggaran tata tertib sekolah, tawuran, mengkonsumsi moniman keras atau rokok, menjadi pecandu napza serta pergaulan bebas (free seks).

Penampilan perilaku remaja seperti tersebut di atas sangat tidak diharapkan, karena tidak sesuai dengan sosok pribadi manusia Indonesia yang dicita-citakan, seperti yang tercantum dalam tujuan pendidikan nasional (Undang-undang Republik Inonesia nomor 20 tahun 2003 tentang Sistem Pendidikan nasional), yaitu beriman dan bertaqwa terhadap Tuhan Yang Maha Esa, berakhlak mulia, sehat jasmani rohani, berkepribadian mantap dan mandiri, serta memiliki rasa tanggung jawab kemasyarakatan dan kebangsaan. Sebagian besar masyarakat, lebih-lebih masyarakat tidak terdidik mempersepsikan pendidikan hanya sebagai pembelajaran. Masyarakat atau orangtua akan berbangga kalau putra-putri mereka pintar dalam mata pelajaran. Pujian akan datang dari berbagai pihak apabila anak-anak mereka berhasil memenangkan lomba-lomba mata pelajaran tingkat kabupaten atau di tingkat yang lebih tinggi. Masyarakat yang demikian mempersepsikan pendidikan intelek sebagai modal keberhasilan hidup. Sedangkan aspek lain seakan-akan tidak menjadi skala prioritas dalam pengembangannya. Jadi orang yang pintar adalah orang yang akan berhasil dalam hidupnya.

Terkait beberapa isu di atas dan melihat kenyataan bahwa masalah penyalahgunaan napza di kalangan siswa di indonesia semakin memprihatinkan, dengan presentse kasus dari tahun ke tahun selalu meningkat maka diperlukan adanya keseimbangan pengembangan 
aspek intelektual (kognitif) dengan pengembangan non kognitif seperti pengembangan emosi. Karena keduanya memiliki nilai yang penting bagi kehidupan manusia.

Berkaitan dengan hal itu, Daniel Golemen (1998:44) menyebutkan bahwa banyak perkecualian terhadap pemikiran yang menyatakan bahwa IQ meramalkan kesuksesan-kesuksesan ... banyak (atau lebih banyak) perkecualian daripada kasus yang cocok dengan pemikiran itu...." dan itulah masalahnya; kecerdasan akademis praktis tidak menawarkan persiapan untuk menghadapi gejolak atau kesempatan yang ditimbulkan oleh kesulitan-kesulitan hidup. Namun, bahkan IQ yang tinggi pun tidak menjamin kesejahteraan, gengsi, atau kebahagiaan hidup; sekolah dan budaya kita lebih menitikberatkan pada kemampuan akademis, mengabaikan kecerdasan emosional, yaitu serangkaian ciri-ciri... sebagian yang ada menyebutkan karakter... yang juga sangat besar pengaruhnya terhadap nasib kita. Sementara itu, Ary Ginajar Agustian (2001:41) juga menyebutkan bahwa "Kebanyakan program pendidikan hanya berpusat pada kecerdasan akal (IQ), padahal diperlukan pula bagaimana mengembangkan kecerdasan emosi seperti, ketangguhan, inisiatif, optimisme, kemampuan beradaptasi. Saat ini begiutu banyak orang berpendidikan yang tampak begitu menjanjikan, mengalami kemandegan dalam kariernya. Lebih buruk lagi, mereka tersingkir akibat rendahnya kecerdasan emosi". Senada dengan pendapat di atas, Tilaar (1999: 137) juga menyebutkan bahwac "manusia seutuhnya berarti mengembangkan seluruh aspek pribadinya, yaitu iman dan taqwa kepada Tuhan, budi pekerti yang luhur, penguasaan pengetahuan dan keterampilan, kesehatan jasmani dan rohani, kepribadian yang mantap dan mandiri, mempunyai rasa tanggungjawab kemasyarakatan dan kebangsaan". Pendapat yang serupa juga disebutkan oleh Sunaryo Kartadinata (2000:6) bahwa "keberhasilan atau prestasi yang dicapai manusia masyarakat global, tidak sematamata ditentukan oleh kecerdasan intelektual tetapi juga oleh kekuatan, komitmen, motivasi, kesungguhan, disiplin dan etos kerja, kemampuan beempati, berinterelasi dan berintrarelasi."

Uraian di atas menuntut perlu segera disikapi dan ditindaklanjuti untuk merancang berbagai model interaksi atau model perlakuan (treatment) untuk mencegah keterlibatan siswa dalam penyelahgunaan napza, yang dapat mengkontribusi pendidikan afeksi yang lebih komprehensif melalui penanaman nilai-nilai, penemuan makna hidup, semangan spisitual dalam kehidupan sehari-hari diskusi, penghayatan terhadap nilai, dan sebagainya. Kenyataan menggambarkan di lapangan bahwa dengan adanya Bimbingan Konseling (BK) di sekolah, pada umumnya sudah dapat menangani berbagai permasalahan yang memang merupakan kajian dan tugas BK itu sendiri, baik itu bimbingan pribadi, sosial, belajar dan bimbingan karir. Salah satunya adalah menangani masalah penyalahgunaan napza di kalangan siswa. Sudah tentunya hasil dari penanganan permasalahan ini sangat penting untuk dikaji karena penyalahgunaan napza meruapakan masalah nasional yang dapat mengancam terhambatnya kelangsungan generasi bangsa.

Dalam menanggapi permasalahan tersebut dan terkait dengan kewajiban konselor sekolah, maka sudah tentunya dibutuhkan model bimbingan konseling yang efektif untuk mencegah penyalahgunaan napza. Model Konseling logo merupakan salah satu model dalam pelayanan konseling di sekolah yang menitik beratkan pada pengembalian makna hidup dan penemuan jati diri siswa. Konseling Logo merupakan proses pemberian bantuan dari konselor kepada konseli dalam wawancara konseling yang berlandaskan pada pencarian makna hidup 
dan simbol-simbol spiritual yang bertujuan agar siswa bisa lebih memaknai hidupnya dan mengembangkan hidupnya menjadi lebih baik (Frankl, 2010). Konseling Logo sebagai corak psikologi eksistensial humanistik yang mengakui adanya dimensi kerohanian pada manusia di samping dimensi ragawi dan kejiwaan, serta beranggapan bahwa makna hidup (the meaning of life) dan hasrat untuk hidup bermakna (the will of meaning) merupakan motivasi utama manusia guna meraih taraf kehidupan bermakna (the meaningful life) yang didambakannya. Melalui model konseling logo siswa terbantu membangkitkan diri mereka yang teluka, meningkatkan makna hidup dan penemuan jati diri untuk hidup lebih berguna, bermakna dan bertujuan secara logis dan normatif. Konseling Logo bertujuan agar konseli (siswa) dapat menemukan makna dari penderitaan dan kehidupan serta cinta dalam masalah yang dihadapinya. Dengan penemuan itu siswa akan dapat membantu dirinya sehingga bebas dari masalah tersebut. Konseling Logo berorientasi pada masa depan (future oriented) dan berorientasi pada makna hidup (meaning oriented). Relasi yang dibangun antara konselor dengan konseli adalah encounter, yaitu hubungan antar pribadi yang ditandai oleh keakraban dan keterbukaan, serta sikap dan kesediaan untuk saling menghargai, memahami dan menerima sepenuhnya satu sama lain (Frankl, 2010). Berdasarkan uraian tersebut, diprediksi model konseling logo mampu meminimalkan gejala-gejala kecenderungan penylahgunaan napza siswa melalui peningkatkan ketahanan mental spritual, sikap dan perilaku siswa, kesadaran diri, penemuan makna hidup, mampu mengatasi masalah sendiri dan tidak terpengaruh terhadap pergaulan yang mengarah pada perilaku negatif yang menjadi gerbang ke arah penyalahgunaan napza sebagai indikator dari kemampuan siswa untuk menghindar dari penyalahgunaan napza.
Penelitian ini bertujuan mengembangkan model konseling logo untuk mencegah penyalahgunaan napza pada siswa Di provinsi Bali. Secara lebih khusus, penelitian bertujuan: (1) mendeskripsikan kecenderungan penyalahgunaan napza para siswa di Bali, (2) mendeskripsikan persepsi siswa terhadap upaya pencegahan penyalahgunaan napza yang telah dilakukan di sekolah, (3) mengetahui efektifitas model konseling logo secara teoretik melalui uji validasi oleh pakar bimbingan konseling, (4) mengetahui pengaruh model konseling logo terhadap kecenderungan siswa terhadap penyalahgunaan napza.

\section{METODE}

Penelitian ini menggunakan pendekatan pengembangan (research and development atau $R \& D$ ) yang terdiri dari tujuh langkah pokok yaitu, (1) research and information collecting; (2) pllaning; (3) develop preliminary form of product; (4) preliminary field testing and product revision; (5) main field test and product revision; (6) operational field test and product revision; dan (7) dessemination implementastion and institutionalization, (Wolter R. Borg dan Meredith Damien Gall (1989 dalam Dantes, 2007). Penelitian dilakukan pada dua tahap, pada tahap I ini fokus penelitian adalah pada analisis kebutuhan, pengujian model secara teoretik, dan uji pengaruh model secara emperik pada populasi skala kecil.

Populasi penelitian ini adalah siswa pada SMP, SMA dan SMK Negeri dan Swasta di Provinsi Bali, para praktisi yaitu guru BK, serta tokoh-tokoh kunci ahli bimbingan konseling di Bali. Sampel ditentukan secara multi stage random sampling, diperoleh jumlah responden siswa sebanyak 332 yang tersebar di 10 sekolah menengah di beberapa wilayah pada provinsi Bali. Selanjutnya uji coba model secara terbatas melibatkan sampel para siswa kelas X SMK N 1 Singaraja.

Analisis data dalam penelitian ini terdiri dari beberapa tahapan, yakni: (1) 
data kecenderungan penyalahgunaan napza dan dianalisis secara deskriptif selanjutnya dibandingkan dengan kriteria penilaian acuan normatif (Pan) skala lima, dengan kualifikasi kecenderungan yang sangat tinggi, tinggi, sedang, rendah dan sangat rendah; (2) data persepsi terhadap upaya pencegahan penyalahgunaan napza di sekolah dianalisis secara deskriptif dengan teknik persentase; (3) data validasi model teoretik melalui ekpert judgement dianalisis dengan Gregory; dan (4) data hasil eksperimen untuk menguji pengaruh model konseling logo terhadap kecenderungan penyalahgunaan napza dianalisis dengan t-test.

\section{HASIL DAN PEMBAHASAN}

Identifikasi kecenderungan

penyalahgunaan napza siswa menunjukkan bahwa dari 332 respnden ditemukan sebanyak 213 siswa $(64,15 \%)$ memiliki kecenderungan penyalahgunaan napza pada kategori sedang, selanjutnya 85 siswa (25,10\%) pada kategori tinggi, dan 34 siswa $(10,25 \%)$ pada kategori rendah. Persepsi siswa terhadap upaya pencegahan penyalahgunaan napza yang telah dilakukan di sekolah menunjukkan bahwa sebesar $81 \%$ siswa berpersepsi bahwa telah dilakukan upaya pencegahan penyalahgunaan napza di sekolah dan $61 \%$ diantaranya mempersepsikan upaya tersebut dilaksanakan melalui layanan bimbingan konseling oleh konselor sekolah dengan cara mengintergrasikan materi pencegahan penyalahgunaan napza pada kegiatan layanan bimbingan konseling.

Model konseling logo yang dikembangkan terdiri dari beberapa langkah yang meliputi: (1) tahap perkenalan dan pembinaan rapport. Pada tahap ini diawali dengan menciptakan suasana nyaman antara konselor dengan siswa yang semakin lama semakin membuka peluang untuk terjadinya sebuah encounter. Dimana inti sebuah encounter adalah penghargaan kepada sesama manusia, ketulusan hati, dan pelayanan. Percakapan dalam tahap ini tak jarang memberikan efek terapi bagi konseli. (2) tahap pengungkapan dan penjajagan masalah. Pada tahap ini konselor mulai membuka dialog mengenai masalah yang dihadapi konseli. Berbeda dengan konseling lain yang cenderung membeiarkan konseli "sepuasnya" mengungkapkan masalahnya, dalam konseling logo konseli sejak awal diarahkan untuk menghadapi masalah itu sebagai kenyataan. (3) tahap konseling, konselor dan konseli bersama-sama membahas dan menyamakan persepsi atas masalah yang dihadapi. Tujuannya untuk menemukan arti hidup sekalipun dalam penderitaan, (4) tahap evaluasi dan penyimpulan mencoba memberi interpretasi atas informasi yang diperoleh sebagai bahan untuk tahap selanjutnya, yaitu perubahan sikap dan perilaku konseli. Pada tahap-tahap ini tercakup modifikasi sikap, orientasi terhadap makna hidup, penemuan dan pemenuhan makna, dan pengurangan symptom gejala perilaku mengarah pada penyalahgunaan napza. Model konseling logo yang dirumuskan ini dapat dilaksanakan dalam kegiatan konseling dengan format, individual, kelompok maupun secara format klasikal.

Hasil validasi model secara teoretik dengan profesional judgement menunjukkan kofesien validitas Gregory berada pada indeks validitas teoretik yang baik ( $R$ sebesar 0,90). Hal tersebut menunjukkan model yang dikembangkan memenuhi syarat untuk dikembangkan lebih lanjut. Data kualitatif mengenai uji validitas pada konsep dan struktur rancangan model yang dikembangkan pada tahap ini sudah relevan, pada bagian sintaks perlu di sefesifikasikan sehingga lebih aplikatif untuk dilaksanakan di kelas sesuai sasaran pengembangan, implementasi.

Uji coba model secara terbatas melalui ekperimen kepada para siswa kelas XI SMK N 1 Singaraja menunjukkan terdapat pengaruh yang signifikan penerapan model konseling logo terhadap kecenderungan siswa menyalahgunakan 
napza. Hal tersebut dibuktikan dari hasil analisis t-test sebagai berikut:

Tabel 1 Rangkuman uji-t antar kelompok eksperimen dan kelompok kontrol pada amatan akhir dan lanjut

\begin{tabular}{lll}
\hline $\begin{array}{l}\text { Kelompok/ } \\
\text { Waktu Amatan }\end{array}$ & Akhir & Lanjut \\
\hline $\begin{array}{l}\text { Eksperimen, } \\
\text { Kontrol }\end{array}$ & -19.654 & -14.443 \\
$\mathrm{P}$ & $<0.001$ & $<0.001$
\end{tabular}

Tabel 1 tentang rangkuman uji-t antar kelompok ekperimen dan kelompok kotrol pada amatan akhir dan lanjut di atas menunjukkan bahwa nilai t pada amatan akhir setelah kelompok eksperimen mengikuti model sebesar -19,654 dengan $p<0,05$ yang berarti terdapat perbedaan penurunan kecenderungan penyalahgunaan napza yang signifikan antara siswa kelompok eksperimen dan kelompok kontrol pada amatan akhir. Selanjutnya pada amatan lanjut, nilai $t$ sebesar $-14,443$ dengan $p<0,05$ menunjukkan bahwa perbedaan penurunan tersebut masih terjadi meskipun kegiatan konseling logo telah dihentikan pada kelompok eksperimen. Dari hasil analisis data tersebut dapat dibuktikan bahwa penerapan konseling logo berpengaruh pada penurunan tingkat kecenderungan penyalahgunaan napza oleh siswa.

Bukti lain berupa hasil pengamatan melalui buku harian kelompok siswa eksperimen yang diisi selama mereka mengikuti kegiatan konseling logo juga menunjukkan peningkatan kualitas pemaknaan hidup para siswa dari minggu pertama pelaksanaan konseling sampai dengan minggu terakhir pelaksanaan konseling diakhiri. gambaran yang lebih jelas dapat dilihat pada gambar grafik 1 berikut.

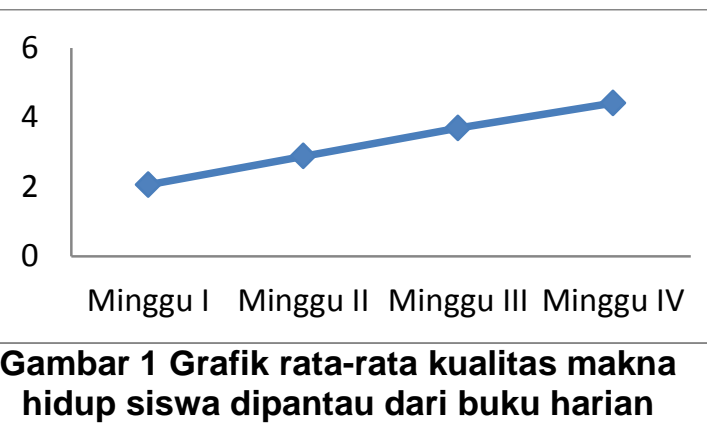

Berdasarkan gambar 1 di atas dapat dilihat bahwa para siswa peserta kegiatan mengalami peningkatan dalam memaknai hidupnya, dari awal kegiatan sampai akhir kegiatan. Data persepsi siswa terhadap konseling logo yang diperoleh melalui angket menunjukkan 85\% siswa merasakan senang mengikuti kegiatan konseling logo, sedangkan $15 \%$ lainnya belum benar-benar paham bagaimana mengikuti kegiatan konseling logo untuk meningkatkan pemaknaan terhadap hidup. Mereka yang telah mampu mengikuti kegiatan konseling logo dengan baik menyatakan melalui kegiatan konseling logo, masalah ketidakjelasan makna dan tujuan hidup dapat teratasi, mereka juga merasakan telah mampu dengan sadar mengambil jarak terhadap dirinya serta mampu meninjau dan menilai dirinya sendiri sehingga lebih bisa menjadikan hidupnya lebih bermanfaat dan bisa lebih bertanggung jawab dengan hidupnya.

Berdasarkan uraian temuan penelitian di atas terdapat beberapa hal yang perlu dikaji dan dimaknai. Yang pertama, temuan mengenai identifikasi kecenderungan penyalahgunaan napza di kalangan siswa beberapa wilayan di Bali yang menunjukkan adanya $25 \%$ siswa yang memiliki kecenderungan penyalahgunaan napza pada tingkat tinggi, dan $61 \%$ pada kategori sedang menunjukkan rentannya siswa kita disekolah untuk terjerumus dalam penyalahgunaan napza. Hal ini juga hendaknya dapat dijadikan acuan bahwa kurikulum di persekolahan perlu lebih 
banyak memperhatikan pengembangan aspek non-intelektual siswa diamping mengembangan kecakapan intelektual dan penguasaan materi pelajaran. Karena pada hakekatnya pendidikan adalah upaya untuk mengembangkan dan menyeimbangkan kecerdasan intelektual dan non-intelektual siswa. Persepsi siswa terhadap penyelengaraan upaya pencegahan penyalahgunaan napza di sekolah menunjukkan bahwa sebagian besar siswa berpersepsi bahwa sekolah sudah melaksanakan upaya pencegahan penyalahgunaan napza yang dominan dilakukan oleh guru BK dengan mengintergrasikan materi penyalahgunaan napza di sekolah dalam pelayanan BK. Hal tersebut perlu didukung dengan upaya penerapan model-model atau teknik konseling yang relevan dengan permasalahan yang ingin diatasi.

Hasil uji coba model konseling logo secara secara teoretik melalui uji pakar menunjukan nilai validitas model secara teoretik yang baik dan bukti lain hasil uji coba secara emperik melalui ekpserimen subjek terbatas menunjukkan bahwa penerapan model konseling logo memberikan dampak positif terhadap upaya pencegahan penyalahgunaan napza dengan bukti meningkatnya pemaknaan hidup siswa dan menurunnya kecenderungan penyalahgunaan napza setelah para siswa dilibatkan dalam kegiatan konselig logo. Siswa yang mengikuti kegiatan konseling dengan model logo mampu mengembangkan pemahaman dan sikap yang lebih tinggi untuk menghindarkan diri dari kecenderungan penyalahgunaan Napza dan siswa juga lebih bisa memaknai hidupnya. Hal ini menunjukkan bahwa konseling logo dapat membantu siswa dalam mencegah kecenderungan penyalahgunaan Napza.

Bukti lain yang mendukung penelitian ini menunjukkan bahwa pada awal pemberian layanan banyak siswa yang belum memahami dan belum memiliki kesadaran diri, optimisme dan komitmen terhadap kecenderungan penyalahgunaan napza. Siswa juga belum memahami bagaimana cara untuk memaknai hidupnya. Selanjutnya pada akhir kegiatan konseling (treatment) siswa menunjukkan perubahan yaitu para siswa peserta konseling logo memperoleh cara untuk menemukan hidup bermakna dengan jalan merealisasikan tiga nilai kehidupan, yaitu (1) nilai-nilai kreatif (creative values), seperti nilai-nilai kreatif kegiatan berkarya, bekerja, menciptakan serta melaksanakan tugas dan kewajiban sebaiknya dengan penuh tanggung jawab. (2) nilai-nilai penghayatan (eksperiental values) yaitu keyakinan dan penghayatan akan nilai-nilai kebenara kebajikan, kemndahan, keimanan, dan keagamaan, cinta kasih. Menghayati dan meyakini suatu nilai dapat menjadikan seseorang berarti hidupnya. (3) nilai-nilai bersikap (attitudinal values), yaitu menerima dengan penuh ketabahan, kesabaran, dan keberanian segala bentuk penderitaan yang tidak mungkin dielakkan lagi, seperti sakit yang tak dapat disembuhkan, kematian, dan menjelang kematian, setelah segala upaya dan ikhtiar dilakukan secara maksimal. Hal tersebut dapa dilihat dari perkembangan positif siswa yang dipantau melalui grafik buku harian siswa selama melalui kegiatan. Grafik tersebut menggambarkan kemajuan yang secara signifikan dari setiap pertemuan kegiatan konseling yang dicapai siswa baik secara individu maupun secara kelompok.

Hasil penelitian juga menemukan bahwa siswa peserta kegiatan konseling logoi memberikan persepsi yang baik terhadap konseling logo. siswa peserta kegiatan menunjukkan bahwa mereka berhasil menemukan makna hidupnya, mereka mampu mengatasi masalah ketidakjelasan makna dan tujuan hidup, mampu melakukan self-detachment, yakni dengan sadar mengambil jarak antara bentuk-bentuk perilaku mengarah ke penyalahgunaan napza dengan dirinya dirinya serta mampu meninjau dan menilai 
kelemahan dan kekuatan dirinya sendiri. Konseling logo berorientasi pada masa depan (future oriented) dan berorientasi pada makna hidup (meaning oriented) sehingga lebih bisa menjadikan hidupnya lebih bermanfaat dan bisa lebih bertanggung jawab dengan hidupnya.

Hal tersebut senada dengan inti dari kegiatan konseling logo yang diungkapkan Frankl (1992) yakni: (1) hidup itu memiliki makna (arti) dalam setiap situasi, bahkan dalam penderitaan dan kepedihan sekalipun. Makna adalah sesuatu yang dirasakan penting, benar, berharga dan didambakan serta memberikan nilai khusus bagi seseorang dan layak dijadikan tujuan hidup, (2) setiap manusia memiliki kebebasan yang hampir tidak terbatas untuk menentukan sendiri makna hidupnya. Dari sini kita dapat memilih makna atas setiap peristiwa yang terjadi dalam diri kita, apakah itu makna positif atupun makna yang negatif. Makna positif ini lah yang dimaksud dengan hidup bermakna dan (3) setiap manusia memiliki kemampuan untuk mangambil sikap terhadap peristiwa tragis yang tidak dapat dielakkan lagi yang menimpa dirinya sendiri dan lingkungan sekitar.

Uraian bukti-bukti hasil penelitian tersebut menunjukkan bahwa penerapan konseling logo pada siswa sekolah menengah memberikan pengaruh bagi berkembangnya potensi siswa, khususnya membentuk kepribadian mereka menjadi lebih matang dalam menghargai diri, menentukan jalan hidup yang bermakan dan bertanggung jawab terhadap hidup dan dirinya sendiri. Hasil penelitian tersebut juga menunjukkan bahwa penerapan konseling logo memberikan sumbangan yang positif terhadap kecerdasan spritual siswa. Mereka yang telah mengikuti kegiatan konseling logo lebih mensyukuri hidupnya dan menjaganya dengan baik untuk dapat dipertanggung jawabkan dihadapan Tuhan. Sehingga demikian penerapan konseling logo kepada para siswa di sekolah merupakan salah satu upaya yang strategis untuk mencapai tujuan pendidikan nasional seperti yang diamanatkan Undang-Undang RI No 20 tahun 2003, yaitu membentuk manusia Indonesia beriman dan bertaqwa terhadap Tuhan Yang Maha Esa, berakhlak mulia, sehat jasmani rohani, berkepribadian mantap dan mandiri, serta memiliki rasa tanggung jawab kemasyarakatan dan kebangsaan.

Hasil uji coba model secara emperik di sekolah yang dipaparkan di atas memiliki keterbatasan yakni subjek populasi uji coba terbatas pada satu sekolah saja, sehingga untuk mendapatkan gambaran lebih jelas mengenai dampak faesibilitas model pada subjek populasi yang lebih luas, diperlukan penelitian lanjutan dengan subjek populasi yag lebih luas. Sehingga mendapatkan model konseling logo yang fiks untuk diimplementasikan secara lebih luas di sekolah sekolah di provinsi Bali pada khususnya dan di Inonesia secara umum.

\section{PENUTUP}

Berdasarkan uraian hasil penelitian di atas dapat disimpulkan bahwa: (1) 332 respnden ditemukan sebanyak 213 siswa $(64,15 \%)$ memiliki kecenderungan penyalahgunaan napza pada kategori sedang, selanjutnya 85 siswa $(25,10 \%)$ pada kategori tinggi, dan 34 siswa $(10,25 \%)$ pada kategori rendah; (2) sebanyak $81 \%$ siswa mempersepsikan telah dilakukan upaya pencegahan penyelahgunaan napza di sekolah dan $61 \%$ diantaranya mempersepsikan upaya pencegahan dilakukan oleh konselor sekolah; (3) hasil validasi model secara teoretik melalui ekspert judgement menunjukkan rancangan model yang dikembangkan dinilai memiliki validasi yang baik oleh pakar ( $R$ sebesar $0,90)$ sehingga layak dikembangkan lebih lanjut, (3) hasil ekperimen untuk menguji pengaruh model konseling logo dalam menurunkan kecenderungan penyalahgunaan napza di SMK N 1 Singaraja menunjukkan bahwa para siswa 
yang mengikuti kegiatan konseling logo dapat menurunkan kecenderungan menyalahgunakan napzanya lebih baik dibandingkan dengan kelompok siswa yang tidak dilibatkan dalam kegiatan konseling logo. Grafik buku harian siswa yang mengikuti kegiatan konseling logo juga menunjukkan perkembangan yang positif dari awal kegiatan sampai akhir kegiatan yakni meningkatkan kualitas pemaknaan hidup mereka. Hal tersebut dapat membuktikan bahwa penerapan model konseling logo dapat menurunkan kecenderungan penyalahgunaan napza siswa.

Melalui hasil penelitian ini disarankan kepada para siswa sudah berkesempatan mengikuti kegiatan konseling logo dalam uji coba model melalui eksperimen terutama kepada kelompok agar terus berusaha melakukan kegiatan konseling logo meskipun tidak dipandu oleh konselor agar mampu terus meningkatkan kualitas pemaknaan hidup dan secara penuh keyakinan dan tanggung jawab mampu mencegah keterlibatan diri dalam penyalahgunaan napza. Selanjutnya pengalaman mengikuti kegiatan konseling logo ini agar diinformasikan dan dilatihkan juga kepada siswa lain yang belum berkesempatan mengikuti agar mereka mendapat manfaat kegiatan konseling logo ini. Hasil penelitian ini telah memiliki luaran rancangan model konseling logo yang efektif untuk diaplikasikan di persekolahan untuk mencegah penyalahgunaan napza, selanjutnya kepada para praktisi guru Bimbingan Konseling agar mencoba menerapkan model ini di sekolah tempat bertugas. Kepada peneliti selanjutnya dapat memanfaatkan hasil penelitian ini dengan mengkaji dampak model atau menguji efektifitas model pada populasi yang lebih luas dan memberikan warna-warna tersendiri dalam langkah atau teknik penerapan konseling logo ini. Karena langkah-langkah konseling logo yang dikembangkan dalam penelitian ini bukanlah hal yang kaku, namun bersifat fleksible untuk dilakukan inovasi sesuai dengan kebutuhan.

Ucapan terimakasih diberikan kepada para pakar dan praktisi bimbingan konseling yang dilibatkan dalam penelitian ini, kepada mahasiswa yang membantu pelaksanaan penelitian ini, kepada para siswa yang dilibatkan sebagai responden dan subjek uji coba model, dan semua pihak yang terlibat dalam terlaksananya penelitian ini.

\section{DAFTAR PUSTAKA}

Agustian. A,G. 2001. Rahasia Sukses membangun Kecedasan Emosi. Jakarta: ARGA.

Dantes, Nyoman. 2007. Metodelogi Penelitian untuk IImu-ilmu Sosial dan Humaniora. Singaraja: Universitas Pendidikan Ganesha.

Frankl, Viktor E.1992. Man's Search for Meaning: Fourth edition.. Marquette University Press.

2010. Man's Search for Meaning, looks at the human condition in our times. Marquette University Press.

Goleman,D. alihbahasa T. Hermaya.1998. Emotional Intelligence. Jakarta: Gramedia Pustaka Utama.

Sunaryo Kartadinata. 2000. Pendidikan Untuik Pengembangan Sumberdaya Manusia Bermutu Memasuki Abad XXI, Implikasi Bimbingannya. Bandung: FIP UPI.

Suranata,Kadek. 2009. Efektifitas Layanan Bimbingan Kelompok Untuk Meningkatkan Antisipasif siswa Terhapap Penyalahgunaan Napza. Juranal Penelitian. IKA Undiksha, Vol 8 No 1. hal 112-119.

Tilaar, H.A.R. 1999. Pendidikan Kebudayaan dan Masyarakat Madani Indonesia, Strategi Reformasi Pendidikan Nasional, Bandung PT. Remaja Rosdakarya.

Undang-Undang Republik Indonesia Nomor 20 tahun 2003: Sisdiknas.Jakarta, Fokusmedia. 